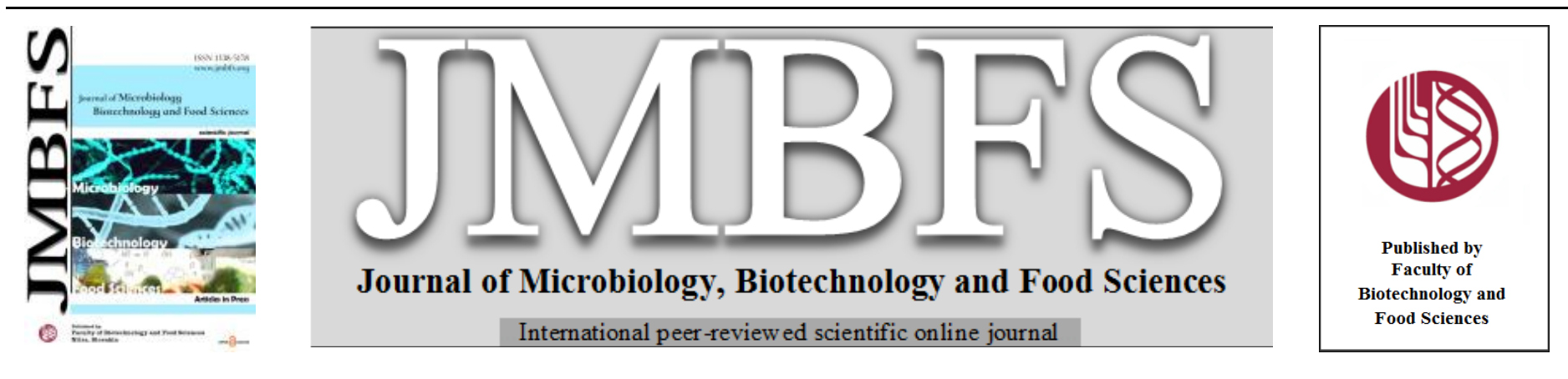

\title{
ZN AS A VITAL MICRONUTRIENT IN PLANTS
}

\author{
Vandana Nandal $^{* 1}$, Manu Solanki ${ }^{2}$ \\ Address(es): Tital (s) Vandana Nandal, \\ ${ }^{1}$ Manav Rachna International Institute of Research and studies, Department of Biotechnology, 121004 Faridabad, Haryana, 7701876408. \\ ${ }^{2}$ Manav Rachna International Institute of Research and studies, Department of Biotechnology, 121004 Faridabad, Haryana, 9811608073.
}

*Corresponding author: vandana27nandal@gmail.com

https://doi.org/10.15414/jmbfs.4026

\section{ARTICLE INFO}

Received 2. 12. 2020

Revised 19. 6. 2021

Accepted 1.7. 2021

Published 1. 12. 2021

\section{Review}

OPEN $\partial_{\text {ACCESS }}$

\begin{abstract}
Macro and micronutrients are vital for the growth and productivity of the plants. Zinc $(\mathrm{Zn})$ is considered to be one of the essential micronutrients for the growth and development of cereals as well as fodder crops. It is also a regulatory cofactor for all those enzymes which are required for the synthesis of chlorophyll, proteins and carbohydrates. The functioning of these enzymes is affected significantly due to $\mathrm{Zn}$ deficiency and there will be a retarded growth and productivity of plants. Deficiency of $\mathrm{Zn}$ is a universal problem among cereal crops. The concentration of $\mathrm{Zn}$ varies from 6-1.2 mg/kg in various soils, whereas its concentration reaches 20-300 ppm in plants. $\mathrm{Zn}$ deficiency leads to chlorosis in the leaves of plants. Various reasons affect the availability of $\mathrm{Zn}$ in the plants, which include soil type, $\mathrm{pH}$ of the soil and availability of other nutrients that work antagonistically for the absorption of $\mathrm{Zn}$. $\mathrm{Zn}$ applied as the fertilizer gets converted into unavailable form by making insoluble complexes and thus not available for plants. Hence the best alternative to this issue is the use of $\mathrm{Zn}$ solubilising bacteria (ZSB). These ZSB will accumulate in the rhizosphere zone of the plants and will reduce the requirement of the applied $\mathrm{Zn}$ fertilizer. It will prevent $\mathrm{Zn}$ toxicity in the soil and will enhance the uptake of other macronutrients like phosphorus to the plants.
\end{abstract}

Keywords: Bio fertilizer, Zn, PGPR, Zn Solubilising Bacteria

\section{INTRODUCTION}

Appropriate nutrition for plants is one of the vital factors for improving the quality and quantity of product obtained from them. Macronutrients and micronutrients are the essential elements needed by the plants from the germination of the seed up to the fully developed plant. Elements that are required in large quantity are categorized as macronutrients, and those that needed in trace amount are micronutrients (Sharma et al., 2013). Micronutrients are very much essential for the growth of plants and their metabolism. The tremendous use of micronutrients in the soil for agricultural purposes cannot be denied. Nutrients like boron $(\mathrm{B})$, chlorine $(\mathrm{Cl})$, copper $(\mathrm{Cu})$, iron $(\mathrm{Fe})$, manganese $(\mathrm{Mn})$, molybdenum $(\mathrm{Mo})$ and $\mathrm{Zinc}(\mathrm{Zn})$ are classified as micronutrients. These metals are considered very significant for plants even if they are taken up in comparatively lesser amounts by the plants (Grusak $\boldsymbol{e t}$ al., 1999). These micronutrients protect plants from various biotic and abiotic stresses by engaging in numerous roles. However, micronutrient deficiency may lead to multiple diseases in plants, which adversely affects the quantity and quality of the plant's products (Huber and Wilhelm, 1988).

$\mathrm{Zn}(\mathrm{Zn})$ plays a phenomenal role as a micronutrient in plants. Even if it is required in small quantities by most of the plants, the correct amount of $\mathrm{Zn}$ is necessary for the proper functioning of several plant physiological pathways that plays a salient role in their growth and development (Mousavi et al., 2011; Yosefi et al., 2011; Cabot et al., 2019). Zn is necessary for various biochemical processes such as synthesis of cytochromes, nucleic acid and activation of enzymes. It is an integral factor of different enzymes playing a significant role in carbohydrates metabolism, oxidation reactions in plants, and various revival mechanisms (Alloway, 2001). $\mathrm{Zn}$ is an essential cofactor for enzymes required for specific protein biosynthesis and prominent in chlorophyll formation. $\mathrm{Zn}$ is necessary for the activity of the enzyme rubisco. Therefore, it has a significant role in regulating the photosynthesis rate in higher plants (Das et al., 2018). Zn is necessary to maintain membrane activity and maturation of seed and stalk of plants with an increased rate. $\mathrm{Zn}$ also has an intrinsic role in auxin formation, which assists the growth of plants (Barman et al., 2018). Hence $\mathrm{Zn}$ has an indispensable role in plant development and its productivity.

Cakmak. (2000) note that around $50 \%$ of the land utilized for growing crops across the world has a low concentration of accessible $\mathrm{Zn}$, which is needed to support crops' yields and hence increase the nutritional value of the grains. $\mathrm{Zn}$ deficit in the soils as well as in the plants has become an issue in most of the countries. The main reasons responsible for the occurrence of this widespread deficiency of $\mathrm{Zn}$ are Zn's solubility in the soils is very low despite enough availability of the total amount of $\mathrm{Zn}$. The deficiency of $\mathrm{Zn}$ in plants is a significant widespread deficiency compared to other micronutrients, which affects the rate of photosynthesis in various cereal crops (Barman et al., 2018). Zn deficiency leads to discolouration of leaf, and this condition is termed chlorosis (Sharma et al., 2013). Zn becomes a prooxidant by generating reactive oxygen species when it is in excess or even deficient in plant cells, leading to damaging the plant cell (Cabot et al., 2019).

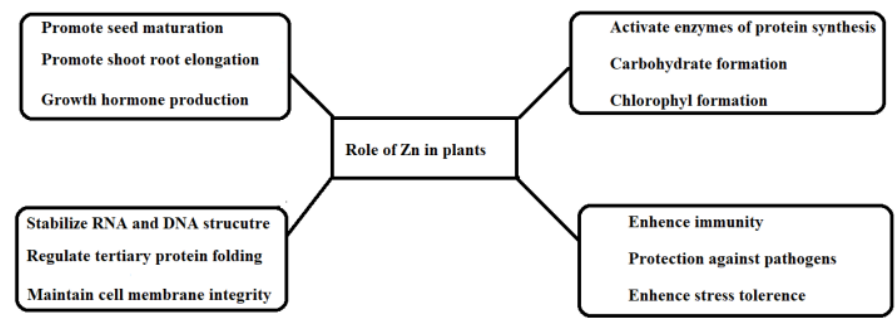

Figure 1 Application of $\mathrm{Zn}$ in Human, Plants, Animals and Microbes

\section{Uptake of zinc chemical fertilizer}

Plants uptake $\mathrm{Zn}$ as a divalent cation $\left(\mathrm{Zn}^{2+}\right)$; however, only a very minute amount of $\mathrm{Zn}$ is readily available as soluble $\mathrm{Zn}$ for plant uptake (Marschner, 1993; Gao et al., 2009). When soluble forms of zinc are applied to the soil in chemical fertilizer, it gets converted into insoluble complexes. It becomes unavailable to the plants leading to the deficiency of $\mathrm{Zn}$ in plants. This results in $\mathrm{Zn}$ deficiency, and there are various methods to assuage this critical problem. The application of $\mathrm{Zn}$ fertilizer is one way to combat $\mathrm{Zn}$ deficiency (Kamran $\boldsymbol{e t}$ al., 2017). $\mathrm{Zn}$ fertilizers are generally used to facilitate crop yields in regions of the $\mathrm{Zn}$ deficit. The utilization of fertilizers containing $\mathrm{Zn}$ increases the productivity of crops (Efe and Yarpuz, 2011). However, the extensive use of fertilizers can cause a myriad of problems like acidification of the soil. When 
$\mathrm{Zn}$ is applied as zinc sulphate, it gets converted to insoluble complexes within seven days. Overuse of zinc sulphate leads to the accumulation of insoluble $\mathrm{Zn}$ in the soil. It causes $\mathrm{Zn}$ toxicity which later inhibits the absorption of other macronutrients, thus behaving antagonistically the absorption of other required nutrients. Under such conditions, further application of $\mathrm{Zn}$ in the next crop resulting in accumulation of $\mathrm{Zn}$ in the soil in a chelated state. When the concentration of total $\mathrm{Zn}$ increases to $100-1000 \mathrm{ppm}$ in soil, it leads to $\mathrm{Zn}$ toxicity. Zn toxicity then becomes a significant issue its deficiency (Marten $\boldsymbol{e t}$ al., 2013). Hence the overuse of chemical $\mathrm{Zn}$ fertilizer will generate the problem of heavy metal toxicity.

Two strategies are employed to overcome $\mathrm{Zn}$ deficiency 1) genetic biofortification 2) agronomic biofortification. Genetic biofortification involves the use of breeding practices and transgenic approaches. In inbreeding practices, the genetic morphology of plants is transformed to create suitable characters However, the developed variety poses specific issues like instability of newly integrated traits. Further, it is a prolonged, labour-intensive technique that may take many years to build and perfected a biofortified variant.

Moreover, the complex laboratory procedures and the high cost involved also present challenges in the practical implementation (Hafeez et al., 2013). The transgenic approach includes augmenting biofortified crops. Abaid-Ullah $\boldsymbol{e t}$ al. (2015) showed that the expression of transcription factors such as bZIP19 and bZIP23 resulted in increased bioavailability of $\mathrm{Zn}$ in the plants. Transport protein of plasma membranes is the main target of $\mathrm{Zn}$ concentration alteration in various regions of plants. In the agronomic approach, $\mathrm{Zn}$ fertilization is given to plants which ensure $\mathrm{Zn}$ translocation for a limited duration. $\mathrm{Zn}$ sulphate, which is transportable, can amplify the supply of Zn concentration within the plants (Kamalakannan et al., 2019).

\section{Rhizospheric bacteria}

The soil is the home of microscopic life forms like fungi, bacteria, algae, and protozoa, found in abundance. Some of them are pathogenic to the plants, some do not interact with them and while others are beneficial. Bacterial cells are found in abundance as compared to others. The type and concentration of bacteria depend upon the $\mathrm{pH}$ of the soil, type of soil, concentration of moisture in it, types of plants grown there, and the nutrients present there. Likewise, the presence and abundance of bacteria are not homogenous in the same soil. The concentration is higher around the roots of the plant. These potential bacteria present in the narrow region of soil around the bases (rhizosphere soil) of most of the plant are called rhizosphere bacteria (Vacheron et al., 2013). This narrow zone of root-soil is very high in nutrient concentration than the overall surface or subsurface soils because of the accumulation of several root exudates, sugar and various amino acids, and the primary nutrients the energy source for microorganisms. This is why the colonization of bacteria in the ecological niches of the root makes their habitat in the root zone (Abaid et al., 2015; Mumtaz et al., 2017).

The way these rhizospheric bacteria will behave depends upon many factors. They can enhance metal absorption and promote plant growth, or they may decrease the absorption of specific macro or micronutrient because of other metal nutrients.). Depending upon their mode of action, bacteria can be categorized as growth-promoting or growth-inhibiting bacteria (Sirohi $\boldsymbol{e t}$ al., 2015). Bacteria that promote plant growth are called plant growth-promoting bacteria or PGPR. All those bacteria that improve plant health and its productivity come under the category of PGPR; they support the development even when the competing microflora is present in the rhizosphere. In General, around $2-5 \%$ of rhizospheric bacteria are in the category of PGPR. Other factors that influence the mechanism of PGPR are the concentration of the nutrients, applied fertilizers or the type of crop grown. One such example is when Pseudomonas fluorescein used to cut blackcurrant stimulates root development whereas works opposite in cherry (Dubeikovsky $\boldsymbol{e t}$ al., 1993). These PGPR can be free-living, live in rhizosphere soil in a symbiotic relationship with the plant, or be entophytic bacteria that live within plant tissue in colonized form. These PGPRs have two mechanisms: the direct one and the indirect one in promoting the plant's growth. Either they provide the plants with the nutrients they take from the soil, or they synthesize the growth hormones, and the indirect way is by inhibiting the attack of pathogens (Glick, 1995). Zn Solubilising bacteria, or we can say $\mathrm{Zn}$ solubilizing PGPR finds their role as bio inoculants as they solubilize the insoluble $\mathrm{Zn}$ forms present in soil by various mechanisms like production of organic acids, decreasing the $\mathrm{pH}$ of the soil, by synthesizing siderophores and by chelating through the output of anions and makes the $\mathrm{Zn}$ available to the plant. The application of PGPR to make the already present zinc available to the plants leads to reduced chemical fertilizers (Liu et al., 2015). As Zn has gained much importance in recent years due to its increased significance in obtaining higher yield and productivity in cereal crops (Dell et al., 1985) and research related to the role played by $\mathrm{Zn}$ in plant growth and human health has generated a great curiosity, and it has become a significantly important topic of study. This review focuses on the role of $\mathrm{Zn}$ in plant growth, its significance as a micronutrient and the application of $\mathrm{Zn}$ Solubilising PGPRs to promote sustainable development and reduce the use of chemical $\mathrm{Zn}$ fertilizer.

\section{Distribution and bioavailability of $\mathrm{Zn}$}

The natural sources of $\mathrm{Zn}$ in soil include weathering of rocks into the soil and atmospheric contributions (fires, dust). In soils, the quantity of total $\mathrm{Zn}$ is distributed in five fractions including the $\mathrm{Zn}$ found in soil solutions, $\mathrm{Zn}$ bound to particles of soil in the form of ions, $\mathrm{Zn}$ complexed with organic ligands, adsorbed $\mathrm{Zn}^{2+}, \mathrm{Zn}$ adsorbed on to clay minerals and insoluble metallic oxides (Alloway, 2001). $\mathrm{Zn}$ is available in the soil as Zones (sphalerite), and sometimes in small quantities as smithsonite $\left(\mathrm{ZnCO}_{3}\right)$, Znite $(\mathrm{ZnO})$, zinkosite $\left(\mathrm{ZnSO}_{4}\right)$; these are $\mathrm{Zn}$ containing mineral ores (Hafeez et al., 2013).Aggregate $\mathrm{Zn}$ profile of soil is mainly dependent on the geographical composition of rocks. The total $\mathrm{Zn}$ content in earth crust is $78 \mathrm{mg}$ of $\mathrm{Zn}$ per $\mathrm{kg}$ of soil (Noulas $\boldsymbol{e t}$ al., 2018). Salah et al. (2015) reported that the concentration of $\mathrm{Zn}$ which is present in soluble form and available to plants is approximately 4 to $270 \mu \mathrm{g} \mathrm{L}-1$ (ppb) in most of the soils. This concentration is too low when it is compared to the total $\mathrm{Zn}$ concentrations that range from 50 to $80 \mathrm{ppm}$. In highly acidic soils, the concentration of soluble $\mathrm{Zn}$ is about $7137 \mu \mathrm{g} \mathrm{L}-1$ which indicates that solubility is strongly linked to and is inversely proportional to $\mathrm{pH}$ of soil. It is reported that concentration. Of $\mathrm{Zn}$ ranges from $10-300 \mu \mathrm{g} \mathrm{Zn}$ g-1 of soil in the majority of arable soils (Gupta et al., 2016). Although $\mathrm{Zn}$ is present in abundance in such soils, a large amount exists in an insoluble form (zinc sulphate, zinc oxide, zinc chloride, zinc phosphate and zinc carbonate) and hence unavailable to the plant. Only the $\mathrm{Zn}$ that can be desorbed easily and is available in soluble fractions is used by the plants, but that fraction of available $\mathrm{Zn}$ is very low. Moreover, the accessibility of $\mathrm{Zn}$ is determined by the physicochemical properties of soils, plant root activity and presence of micro flora in the rhizosphere zone of the plant (Broadley et al., 2007). Zn interacts with chloride, sulphate, phosphate, and nitrate ions to form soluble complexes. Out of these, nitrates, chlorides and sulphates are soluble in water and pose no hindrance in $\mathrm{Zn}$ availability to plants (Prasad et al., 2016). The neutral $\mathrm{Zn}$ phosphate $\left(\mathrm{Zn}_{3}\left(\mathrm{PO}_{4}\right)_{2}\right)$ and $\mathrm{Zn}$ sulphate $\left(\mathrm{ZnSO}_{4}\right)$, species are the very crucial ones as they have been recognized as the prime ones for contributing $\mathrm{Zn}$ in soil solution. Addition of $\mathrm{Zn}$ sulphate leads to increase in the solubility of $\mathrm{Zn}^{2+}$ ions within the soils, Therefore, the presence of acidifying fertilizers, such as ammonium sulphate $\left(\mathrm{NH}_{4}\left(\mathrm{SO}_{4}\right)_{2}\right)$, which reduces the $\mathrm{pH}$ of the soil and makes the soil acidic and hence increase the solubility which leads to the increased availability of $\mathrm{Zn}$ to the plants(Alloway, 2002). The $\mathrm{Zn}$ which was earlier in organically complexed form, after acidification of the soil becomes increasingly mobile. Now when the $\mathrm{Zn}$ exists in its soluble structure in soil then it is easily accessible to plants (Shambhavi et al., 2019).

\section{Adsorption of Zn by soil constituents}

Adsorption and precipitation are two methods which are responsible for regulating the concentration of various ions in the soil. Adsorption of $\mathrm{Zn}$ cations which are exchangeable with other metal cations present in soils is expressed in the simplest way as:

\section{$\mathrm{Zn}^{2+}+\mathrm{X}$-Soil $\leftrightarrows \mathrm{Zn}-$ Soil $+\mathrm{X}^{2+}$}

Where $\mathrm{X}$ is any of the divalent cations.

Cations get attracted to negatively charge solid surfaces in preference and selectivity, which varies based on the various kinds of adsorbents such as hydrous oxides, clay minerals, and sticky substances depending upon the chemical composition of the soil. The cation exchange capacity of soil will determine how efficiently the soil will supply nutrients to plant (Diatta and Kocialkowski, 1998). Speir et al. (2003) studied the adsorption of $\mathrm{Zn}$ on calcareous soil in which severe $\mathrm{Zn}$ deficiency problems in crops is being found. They found that some concentration of total $\mathrm{Zn}$ had been irreversibly fixed to the soil, making the reaction irreversible. According to Alloway (2002), there are two non-identical methods required for $\mathrm{Zn}$ adsorption by the soil and organic matter present in it. One is the cation exchange method, which is primarily applicable for acidic soil conditions and other alkaline soils, mostly involving chemisorptions and complex formation by organic ligands.

\section{Factors affecting the $\mathrm{Zn}$ availability to plants}

Many factors are responsible for affecting the $\mathrm{Zn}$ availability to plants, such as the total content of $\mathrm{Zn}$ present in the soil. The solubility of $\mathrm{Zn}$ in the soil is very low; hence many times, despite sufficient concentration in the soil, the $\mathrm{Zn}$ availability to plant remains low. As $\mathrm{Zn}$ is a trace element, it occurs in the soil in various chemical forms that affect its availability to the plants. It remains surrounded by various metals; it does not get accumulated on the soil surface; instead, it makes complexes with other heavy metals and gets precipitated. This matrix of $\mathrm{Zn}$ with aluminium, iron and manganese oxides, and other silicates and carbonates, impose their control over the availability of $\mathrm{Zn}$ to the plants (Alloway, 2008). The $\mathrm{pH}$ of the soil is also one of these factors. In highly acidic soils, the mean value of available $\mathrm{Zn}$ is around $7.12 \mathrm{ppm}$, indicating that the concentration of soluble $\mathrm{Zn}$ is strongly associated with the $\mathrm{pH}$ and is inversely proportional to the $\mathrm{pH}$ of soil. It was reported that the concentration of total $\mathrm{Zn}$ 
ranges from 10-300 ppm of the majority of agricultural soils (Gupta et al., 2016). At the same time, the total concentration of available $\mathrm{Zn}$ decreases by 100 folds for every unit of $\mathrm{pH}$ increase (Moreno Jiménez et al., 2019). Another reason affecting $\mathrm{Zn}$ availability to crops is the profile of the soil, geology and erosive processes, clay consistency, calcium carbonate available in the soil, redox conditions of the land, moisture status of soil, the concentration of various other micronutrients, macro-nutrients availability importantly phosphorus and climate conditions of the area control the sorption-desorption process of $\mathrm{Zn}$ ions in the soil and cumulatively affect the availability of $\mathrm{Zn}$ to plants (Rutkowska et al., 2015). Organic matter present in the soil also affects its availability. Such calcareous soil has low organic matter; hence, $\mathrm{Zn}$ remains in an inactivated form (Barman et al., 2018). Microbial activity present in the rhizosphere zone of the plant controls the amount of $\mathrm{Zn}$ that will be made available to the crop. It is also affected by various anthropical activities, such as the application of fertilizers, over-irrigation, and industrialization near the agricultural and urban sewage discards. (Dos Santos et al., 2013). These factors cumulatively hinder or facilitate $\mathrm{Zn}$ availability to plants.

\section{Uptake and translocation of $\mathrm{Zn}$ in plants}

Assimilation of $\mathrm{Zn}$ micronutrient from the soil surface to the rhizosphere of a plant is the principal approach for its accretion inside the plant precedent to its transportation to seeds (Hafeez et al., 2013). Although the $\mathrm{Zn}$ uptake changes amid different species, it is usually calculated via the composition and concentrations of the media used for growth (Tsonev and Lindon, 2012). The assimilation of $\mathrm{Zn}$ varies among the grains of different crops and their species (Wu et al., 2010). Zn concentrations in different cultivars of rice are found to be very different (Yang et al., 1998; Graham et al., 1999). The mechanisms through which $\mathrm{Zn}$ gets transferred from soil to plant are much explored and understood. The basic physiology of varied $\mathrm{Zn}$ uptake efficiency is well documented (Wheal $\boldsymbol{e t}$ al., 1997; Hacisalihoglu $\boldsymbol{e t}$ al., 2003; Genc $\boldsymbol{e}$ al., 2009; Widodo et al., 2010). However, the translocation of $\mathrm{Zn}$ and its redistribution after entering the transpiration stream is very meagre. Jiang $\boldsymbol{e}$ al. (2007) reported that $\mathrm{Zn}$ accumulation is related to many factors amongst which its uptake by the root system plays a crucial role. $\mathrm{Zn}$ status within the plant is further dictated by the redistribution and remobilization of stored $\mathrm{Zn}$. $\mathrm{Zn}$ uptake by the plant occurs when $\mathrm{Zn}$ complexes with organic ligands or is available in its divalent ion form. Uptake of zinc follows a linear relationship with its concentration in soil or solution of nutrients (Tsonev and Lindon, 2012). The $\mathrm{Zn}$ is transported from the roots to the shoot tissues through the xylem. Later, apoplast help in the translocation of $\mathrm{Zn}$ to xylem of roots (Broadley et al., 2007). Moreover, it is found that the phloem also had high levels of $\mathrm{Zn}$, it indicates that $\mathrm{Zn}$ is translocated to the plants leave by both phloem and xylem tissues (Haslett et al., 2001).

$\mathrm{Zn}$ is primarily absorbed by roots as $\mathrm{Zn}^{2+}$ from the soil solution or as $\mathrm{Zn}(\mathrm{OH})_{2}$ when the $\mathrm{pH}$ of the soil is high. The process is found to be regulated by proteins having high affinity for $\mathrm{Zn}$. Wheal et al. (1997) proposed that $\mathrm{Zn}$ is transported inside the plant cell towards larger negative electrical potential and this process is thermodynamically passive. It is also found that metabolic inhibitors do not have any impact on $\mathrm{Zn}^{2+}$ uptake and therefore the process of $\mathrm{Zn}$ uptake is independent metabolically. Irrespective of the kinetics of $\mathrm{Zn}$ uptake, its mobility in plants occurs via making a bond with light organic compounds in xylem fluids (Salah $\boldsymbol{e t}$ al., 2015). Bowen $\boldsymbol{e t}$ al. (1974) studied the impact of temperature on adsorption of $\mathrm{Zn}$ in Pinus radiate roots and demonstrated that $\mathrm{Zn}$ absorption by plant roots is inhibited by low temperatures

\section{Biochemical and physiological functions of $\mathrm{Zn}$ in plants}

The metabolic attributes of $\mathrm{Zn}$ are assigned to its capacity of forming complexes with $\mathrm{N}, \mathrm{O}$ and $\mathrm{S}$ inside the plant cells. Intracellular $\mathrm{Zn}$ remains inactivated by forming nexus with organic ligands (Tsonev and Lindon, 2012). $\mathrm{Zn}$ affects the uptake of water and its transportation capacity inside the plants (Kasim, 2007; Disante et al., 2010). $\mathrm{Zn}$ is also found to decrease the negative consequences of heat and salt stress (Peck and McDonald, 2010; Tavallaliet al., 2010). It is actively involved in the synthesis of auxin, which is an essential growth hormone. $\mathrm{Zn}$ is needed to synthesize tryptophan, which leads to IAA (a heteroauxin) synthesis by activating tryptophan synthetase (Brown et al., 1993; Castillo-González et al., 2018). Zn has an active role in the transduction of the signals (Hänsch and Mendel, 2009). Zn also acts as the prosthetic group of several enzymes such as RNA and DNA polymerases, aldolases, dehydrogenases, isomerases, and Trans phosphorylases (López-Millán $\boldsymbol{e t}$ al., 2005). Zn is a catalytic as well as structural protein cofactor in thousands of proteins. There are three $\mathrm{Zn}$ ligands binding sites, namely structural, catalytic, and catalytical. Structural $\mathrm{Zn}$ sites make sure proper protein folding by $\mathrm{Zn}$. In catalytic sites, $\mathrm{Zn}$ is directly included in the catalytic functioning of enzymes. In a catalytical site, $\mathrm{Zn}$ is present in close propinquity and is connected via glutamic acid (Glu), Aspartic acid (Asp) or histidine (His) and bound by water (Broadley et al., 2007). Protein synthesis and energy production are dependent on $\mathrm{Zn}$. $\mathrm{Zn}$ is involved in regulating various biochemical reactions in the process of photosynthesis and is needed for repairing the photosynthetic apparatus, as it turns over the D1 protein that gets photo-damaged (Bailey et al., 2002; Hänsch and Mendel, 2009).

$\mathrm{Zn}$ finger protein arbitrates protein-protein interactions (Cabot et al., 2019). Zn helps preserve the structure of macromolecules and has a primary role in the maintenance of cellular membrane integrity by making interaction with sulfhydryl groups and phosphor lipids of membrane proteins. It also aids in maintaining the transportation of ions within plant cells (Disante et al., 2010; Salah et al., 2015). The plant cell membranes destabilized due to $\mathrm{Zn}$ deficiency could not be reversed quickly. They could lead to the accumulation of boron and phosphorus due to their non-selective entry of boron in the $\mathrm{Zn}$ deficient roots and leaves (Holloway, 1996). $\mathrm{Zn}$ is needed for synthesizing nucleic acids; it also maintains the stability of nucleic acids by forming complexes (Coleman, 1992). It is also involved in the metabolism of lipids (Marschner, 1993). It is observed that $\mathrm{Zn}$ deficient plant is also deficient in its protein content, which occurs due to the deformation of ribosomes. A significant reduction in the synthesis of both RNA and ribosomes in the plant occurs due to Zn deficiency. This shows that $\mathrm{Zn}$ is also required for protein synthesis (Brown et al., 1993). $\mathrm{Zn}$ is needed for carbohydrate fixation. It regulates the formation of reactive bicarbonate species from carbon dioxide, especially in $\mathrm{C} 4$ plants and maintains a high CA activity. $\mathrm{Zn}$ aids in the active functioning of PEP carboxylase by shifting the equilibrium in favour of its substrate $\mathrm{HCO}_{3}$ and maintains enough supply of $\mathrm{HCO}_{3}$ in guard cells where $\mathrm{Zn}$ also determines the $\mathrm{K}^{+}$ion influx (Brennan, 2005; Sharma et al., 2013). Zn plays a vital role in carbonic anhydrase activity. $\mathrm{Zn}$ is also needed for the respiratory enzyme, quinone assimilation, and altering amino acids and protein (Castillo-González et al., 2018).

In addition to this, $\mathrm{Zn}$ also prevents damage of membrane, which is caused by Reactive Oxygen Species (ROS) and is needed for the synthesis of an antioxidant enzyme that is $\mathrm{H} 2 \mathrm{O} 2$ scavenging ascorbate peroxidase which is synthesized in response to the oxidative stresses (Alscher $\boldsymbol{e t}$ al., 1997; Cakmak, 2000). One of the primary functions of $\mathrm{Zn}$ is the regulation and expression of genes as $\mathrm{Zn}$ finger transcription factors. These are involved in the regulation mechanism of various biological processes like flowering, pathogen responses and photomorphogenesis (Castillo-González et al., 2018). Zn is also found to be vital for flowering and seed production. Brown $\boldsymbol{e t}$ al. (1993) demonstrated that when $\mathrm{Zn}$ deficient plants are treated, it has increased the number of inflorescences and yield of seeds compared to the production of dry matter or the seed size in subterranean clover. Metal response elementbinding transcription factor 1 , a $\mathrm{Zn}$ discerning molecule, responds to free levels of $\mathrm{Zn}$ by regulation of gene expression to sustain homeostasis of $\mathrm{Zn}$. $\mathrm{Zn}$ acts on intracellular signalling molecules by imitating the actions of hormones, growth factors and cytokines. It also inhibits the protein tyrosine phosphatase (Yamasaki et al., 2007).

\section{Zn and its interaction with metalloenzyme in plants}

$\mathrm{Zn}$ is a substantial part of an enzymatic cofactor. A cofactor is a component present in the enzymes and enhances their catalytic activity. An enzyme needs a metal ion to initiate the catalytic activity; therefore, metal ions are a significant part of most of the cofactors. Most of the metal ions have a close interaction with the respective enzymes. The trace metal ions link the substrate to their respective enzyme. Hence the ions accept electrons; they stabilize the structure of enzymes and regulate the speed of biochemical reaction (Eide, 2011).

$\mathrm{Zn}$ is very crucial for various plant enzyme systems, including Carbonic anhydrase, several dehydrogenases: alcohol dehydrogenase, glutamic dehydrogenase, L-lactic dehydrogenase, malic dehydrogenase, Dglyceraldehyde-3- phosphate dehydrogenase, and D-lactate dehydrogenase, Aldolase Carboxypeptidase, Alkaline phosphatase, Superoxide dismutase, RNA polymerase, Ribulose bi-phosphate carboxylase, and Phospholipase (Sharma $\boldsymbol{e t}$ al., 2013). Unlike other micronutrients, $\mathrm{Zn}$ is present as a transition element and does not undergo a change in valency and exists only as $\mathrm{Zn}$ (II) in plants ((Patel et al., 2007). In plants, nearly $70 \mathrm{Zn}$ containing metalloenzyme have been reported to date (Zastrow and Pecoraro, 2014). $\mathrm{Zn}$ is a structural, functional and regulatory cofactor of the enzymes belonging to all the enzyme classes. $\mathrm{Zn}$ is omnipresent of all metallic cofactors, and more than 300 enzymes have $\mathrm{Zn}$ as a cofactor. As $\mathrm{Zn}$ exists in the $\mathrm{Zn}^{2+}$ form, therefore; it does not have any redox properties (McCall et al., 2000). It makes substantial nexus with free radicals of the polar groups that contain N, O and S (Alloway, 2001; Lin et al., 2005). Atoms of $\mathrm{Zn}$ that are tightly bound to the apoenzyme are difficult to remove even if they are chemically treated. $\mathrm{Zn}$ usually bound through imidazole and cysteine rings in enzymes requiring $\mathrm{Zn}$ for their activity. The binding of a water molecule to the cooperative is required for the catalytic activity of $\mathrm{Zn}$. Therefore, catalytic $\mathrm{Zn}$ makes the bond with one molecule of water and three protein ligands. On the other hand, in all those enzymes where $\mathrm{Zn}$ has a regulatory or structural role, $\mathrm{Zn}$ bound with four ligands (Auld and Bergman, 2008).

Alcohol dehydrogenase catalyzes reverse oxidation; the enzyme has two $\mathrm{Zn}$ atoms. The first one is for catalytic function and the second one has a structural function. Alcohol produced under anoxic condition because of waterlogging is 
metabolized by alcohol dehydrogenase. The anoxic condition leads to oxygen reduction in soil. This can result in the production of toxic substances and increase the concentration of various natural compounds like carbon dioxide, organic acids, sulphides, and hydrocarbons (gaseous). During $\mathrm{Zn}$ deficit, alcohol dehydrogenase activity subsides to a low limit. Moreover, this limitation is linked to reducing root binding capacity (Hafeez et al., 2013).

Carbonic anhydrase, a metalloenzyme that requires a $\mathrm{Zn}$ cofactor, catalyzes instant change of carbon dioxide and water to bicarbonate ion $\left(\mathrm{HCO}^{3-}\right)$ and a proton. $\mathrm{Zn}$ ions activate the catalytic site of the enzyme by reacting with water and thus catalyzing carbonic anhydrase. The enzyme is responsible for numerous operations like $\mathrm{pH}$ regulation, photosynthetic $\mathrm{CO}_{2}$ fixation, respiration, $\mathrm{CO}_{2}$ transfer, ion exchange and stomata closure. Carbonic anhydrase is required in numerous physiological processes. Any alterations in Carbonic anhydrase activity promptly impact the photosynthetic fixation of carbon dioxide under the carbon dioxide limiting conditions. Carbonic anhydrase activity is thus dependent on atmospheric carbon dioxide levels. $\mathrm{Zn}$ deficit will eventually affect Carbonic anhydrase and influence all the processes linked to the enzyme (Castillo-González et al., 2018).

Superoxide dismutase (SOD) catalyzes the dismutation of superoxide and hydrogen peroxide. Therefore, it has a role in plant defence against antioxidant. At the active site of an enzyme, $\mathrm{Zn}$ links with copper to form $\mathrm{Cu}-\mathrm{Zn}$ SOD. During $\mathrm{Zn}$ deficiency, SOD activity decreases. There is a surge in oxygen production as $\mathrm{Cu}-\mathrm{Zn} \mathrm{SOD}$ is responsible for controlling the generation of toxic oxygen radicals. As toxic oxygen radicals rise, the plasma membrane permeability also surges. This elevation results in depletion in sugar, amino acid, and potassium (López-Millán et al., 2005). Zn controls the inception of toxic oxygen. It impairs the NADPH oxidation as harmful oxygen-free radicals disintegrate the polyunsaturated fatty acids and phospholipid membrane bonds. $\mathrm{Zn}$ is required to perpetuate membrane integrity as it can bond membrane phospholipid groups and configure tetrahedral groups with cysteine residues (McCracken et al., 2013).

\section{Zn interaction with other nutrients present in the soil}

\section{Interaction with macronutrients}

Interaction of $\mathrm{Zn}$ with other macronutrients and micronutrient is a very crucial factor in plant production. For example, in some soils, nitrogen promotes the growth of plants and changes the $\mathrm{pH}$ of the root area and thus affects the $\mathrm{Zn}$ status of crops, whereas, in many other soils, nitrogen is found to be the significant factor in inhibiting the growth and yield of crops. Thus, nitrogen and $\mathrm{Zn}$ fertilizers, when applied in combination, significantly improved crop yields due to the positive interactions among the two nutrients (Shri et al., 2017). At the same time, Kirk et al. (1995) reported that when nitrogen fertilizers are applied alone, they led to a deficiency of $\mathrm{Zn}$. Nitrogen fertilizer enhances plant growth, but it also shows negative interaction with various other micronutrients, such as copper. Plant growth which is promoted by the application of nitrogen fertilizer, causes reduces copper concentration in the plant, which is further made worse by applying $\mathrm{Zn}$ fertilizer. The application of nitrogen fertilizers exacerbates $\mathrm{Zn}-\mathrm{Cu}$ interaction. In solution culture experiments, many micronutrients such as magnesium, calcium, sodium and potassium are amongst the one that inhibits the $\mathrm{Zn}$ absorption by the plant root system. Within the soil, they affect the $\mathrm{pH}$ of the soil. CaSO4 application decreased the $\mathrm{pH}$ of the soil, so it enhanced the mobility of $\mathrm{Zn}$ ions and expanded uptake by the plants. In contrast, application of the same concentration of $\mathrm{CaCO}_{3}$ led to an increase in $\mathrm{pH}$, which leads to a decrease in free ions and therefore retards the uptake of $\mathrm{Zn}$. (Alloway, 2002; Golubovic et al., 2012).

\section{Interaction with micronutrients}

$\mathrm{Zn}$ interacts with micronutrients such as boron, iron, copper, and manganese and affects the concentrations of these micronutrients in plants. Interaction of $\mathrm{Zn}$ with these metal ions has shown varied responses in plants. Loneragan and Webb (1993) reported that when $\mathrm{Zn}$ is applied with iron, it increases the supply of $\mathrm{Zn}$ to the plants. However, iron concentrations were found to increase in some plants, decreases in some, and even affect Fe concentrations. According to Imtiaz et al. (2003), the use of $\mathrm{Zn}$ fertilizers had adversely affected the concentration and intake of Fe in plants. The Roots of the $\mathrm{Zn}$ deficient plants have shown more iron mobilization from $\mathrm{Fe}^{2+}$ hydroxides compared to the plant roots that have adequate $\mathrm{Zn}$. Zn and copper, both micronutrients, share the same site on the root for absorption. Therefore, the application of $\mathrm{Cu}$ does affect the absorption of $\mathrm{Zn}$ in plants. Interaction of both Manganese and boron with $\mathrm{Zn}$ might have both positive and negative responses in plants regarding the availability, uptake, and assignment of $\mathrm{Zn}$ in the plant. Zn-deficient plants absorb more boron due to decreased membrane function in the plant's root than plants having sufficient Zn (Mousavi et al., 2012).

\section{Role of $\mathrm{Zn}$ in plant defense}

Zn plays a substantial role in plant growth. It has an equally important role in plants defence mechanisms in response to insects and pathogens (Yamasaki $\boldsymbol{e}$ al., 2007). According to Li et al. (2016) application of Zn fertilizers ensure a remarkable decline in disease symptoms in plants. Moreover, Helfenstein $\boldsymbol{e t}$ al. (2015) observed that sometimes a particular concentration of $\mathrm{Zn}$ used against a particular pathogen could make that plant susceptible to other pathogens. It shows that the Zn proteins, which are involved in the plant defence, play a dual role, and they can support as well inhibit the plant growth and the invaders simultaneously. The response of plant and the pathogen towards the application of $\mathrm{Zn}$ is greatly dependent on the ability of pathogens to survive the plant defence mechanisms and whether the applied zinc is inhibiting or combating the pathogen attack. It may also depend on the conditions of the surroundings favouring either the plant or the pathogen (Grewal et al., 2001).

Cabot $\boldsymbol{e t}$ al. (2019) described Zn mediated protein-based mechanisms for plant defence. The mechanism studies address effective plant defence with increased gene expression or enhanced activity of the referred protein function by enhancing $\mathrm{Zn}$ availability to the pant. However, it must be made clear that $\mathrm{Zn}$ proteins alone are not involved in these defence mechanisms; other responses related to $\mathrm{Zn}$ are also combined. Machado et al. (2018) documented that $\mathrm{Zn}$ is involved in two broad-spectrum responses in plant-pest/ pathogen interactions. These include oxidative stress and regulation of $\mathrm{Zn}$ finger proteins. In the case of $\mathrm{Zn}$ deficiency, reactive oxygen species (ROS) are contemplated to be the chief factor accountable for hindrance to plant growth. The plant immune system causes oxidative damage or triggers non-oxidative mechanisms via ROS to combat pathogen attack. The oxygen radicals are triggered by plant defence mechanisms post identification of attack by pathogens on plants. The defence mechanisms mainly are hypersensitive responses and systemic acquired resistance (SAR). The Superoxide dismutase, an antioxidant enzyme that controls the activity of oxygen radicals, is increased during pathogen attack (Gupta $\boldsymbol{e t}$ al., 2012). Plant response to toxic $\mathrm{Zn}$ concentration is via regulating nitric oxide (NO), and systemic defence of plant response against stress is by regulating salicylic acid and jasmonates (JA) (Helfenstein et al., 2015). Response of plant and pathogen towards the application of $\mathrm{Zn}$ also depends on the conditions of the surroundings that can favour either the plant or the pathogen (Cabot et al., 2019).

\section{Deficiency of zinc and appearance of symptoms in crops}

Inadequate supply of $\mathrm{Zn}$ to plants is called $\mathrm{Zn}$ deficiency. $\mathrm{Zn}$ deficiency in crops is a severe problem that predominantly affects food production (Alloway, 2001; Welch and Graham, 2002). Zn deficiency leads to impairment of many essential $\mathrm{Zn}$ dependent physiological functions and has adverse effects on plant growth (Sadeghzadeh, 2013). However, almost all $\mathrm{Zn}$ deficient crops positively responded to $\mathrm{Zn}$ application (Welch and Graham, 2002). The deficiency of $\mathrm{Zn}$ in plants is because of many factors like low $\mathrm{Zn}$ availability, low total soil $\mathrm{Zn}$ concentration, and high levels of nitrogen, calcium carbonate, bicarbonates, organic matter and high $\mathrm{pH}$ soil. $\mathrm{Zn}$ deficiency is very dominant in sandy soils, calcareous soils, peat soils, clayey soil and the soils that have increased silicon and phosphorus concentration (Alloway, 2001). Soil formed from gneiss and granite is also low in $\mathrm{Zn}$ (Sadeghzadeh, 2013). Soils rich in phosphates also tends to make $\mathrm{Zn}$ unavailable to the plant (Imtiaz, 2003). Spirit al. (2003) also investigated the concentration of $\mathrm{Zn}$ in different types of soil and observed that Spodosols (28 ppm) and luvisols (35 ppm) are $\mathrm{Zn}$ deficient while fluvisols and histosols were found to have higher $\mathrm{Zn}$ concentrations corresponding to (60 ppm) and 58ppm respectively. The submerged soils are predominantly $\mathrm{Zn}$ deficient as submergence and flooding lead to a reduction in available $\mathrm{Zn}$ by forming insoluble $\mathrm{Zn}$ complexes and change in $\mathrm{pH}$. Sajwan (1988) reported that rice cultivation under the submerged conditions requires the transformation of $\mathrm{Zn}$ into amorphous sesquioxide precipitates or franklinite; $\mathrm{ZnFe} 2 \mathrm{O} 4$.Another contributing factor reported was restricted root exploration in highly compacted soils, including high water table. This is particularly true for soils with a marginal Zn status (Alloway, 2002).

$\mathrm{Zn}$ deficiency may also result from seasonal changes and becoming prominent in cold and wet weather conditions. The condition can be accounted for the reduced microbial activity under cold conditions. The low release of $\mathrm{Zn}$ which is complexed with organic matter leads to limited root growth. Zn deficiency may also vary with Crop type (Alam et al., 2010). Different crops have been found to have different comparative sensitivities to the deficiency of $\mathrm{Zn}$. The Food and Agriculture Organization mentioned that approximately $30 \%$ of the agricultural soil worldwide has a deficient level of soluble $\mathrm{Zn}$ accessible to plants (Sillanpaa, 1990).

Zn deficiency might lead to multiple symptoms in plants. Hafeez $\boldsymbol{e}$ al. (2013) reported that in rice seedlings, symptoms of $\mathrm{Zn}$ deficiency usually appear three weeks after transplantation. The symptoms may vary from brown blotches to streaks that cover the entire surface of the older leaves, resulting in stunted growth. In severe cases, the plant may die. Moreover, the plants that recover manifest a delay in maturity and a substantial reduction in yield. Symptoms of zinc deficiency start occurring at the earliest on the new leaves as $\mathrm{Zn}$ cannot be transferred to new tissues from the older ones. The areas between 
nerves start appearing yellow in the leaves (Vitosh et al., 1998). Mousavi (2011) described that in dicots, internode distance and leaf size is shortened due to $\mathrm{Zn}$ deficiency. In monocots (especially corn), bands start appearing in the central nerve on both sides of monocot leaves.

\section{Zn and its association with crop productivity}

It is evident from the studies that $\mathrm{Zn}$ is necessary for the proper functioning of many important plant physiological pathways. Hence, the concentration of $\mathrm{Zn}$ available to plants is very critical (Alloway, 2002). An appropriate amount of $\mathrm{Zn}$ is necessary for the proper regulation of such pathways (Mousavi et al., 2011; Yosefi et al., 2011). The deficiency of $\mathrm{Zn}$ in plants is most widespread throughout the globe compared to the deficiency of other micronutrients (Alloway, 2001). As discussed earlier, $\mathrm{Zn}$ has a vital role in enzyme activation, protein synthesis, and carbohydrates metabolism and revival reactions. Efe and Yarpuz. (2011) reported that the performance of crop and the quality of their products increase by utilizing $\mathrm{Zn}$ containing fertilizers. In contrast, there is a sharp decline in photosynthesis and, therefore the productivity due to the shortage of $\mathrm{Zn}$. $\mathrm{Zn}$ also acts as a regulatory cofactor of many different enzymes other than those associated with photosynthesis. It is a structural constituent of the proteins involved in critical biochemical pathways related to auxin metabolism, carbohydrate metabolism, protein metabolism, photosynthesis, pollen formation, sugars to starch conversion and plants defence mechanism (Alloway, 2001). Therefore plays a significant role in crop production (Graham et al., 1992). Chemical fertilizers are most used to deal with $\mathrm{Zn}$ deficiencies, but the cost of these fertilizers is usually too high. Therefore, there is a need for suitable alternative methods (Alloway, 2002).

\section{PGPR for dealing with Zn deficiency}

Preventing the occurrence of $\mathrm{Zn}$ deficiency and using appropriate management methods to regulate the $\mathrm{Zn}$ concentration in the soil are two ideal ways to deal with the widespread problem of its deficiency (Alloway, 2002; Mousavi et al. 2011). Due to an increased demand for animal and human food, there is a need to increase edible plants and fodder crops. Hence, farmers' application of fertilizers in crops is the most preferred method used to increase productivity following the population's demand. The agricultural departments of various countries focus on enhancing biofertilizers in place of chemical ones. Recently, environment friendly methods are being implemented in agriculture which has led to applying sustainable alternative methods in place of chemical fertilizers (Sindhu $\boldsymbol{e t}$ al. 2019). One such alternative used to achieve increased crop production is the inoculation of microorganisms that enhances the growth of plants and maintains the quality of the soil. These microbes are called "microbial inoculants" or plant growth-promoting rhizobacteria (PGPR) (Abaid et al., 2014)

"Plant Growth Promoting Rhizobacteria" (PGPR) play a central role in promoting sustainable agriculture. PGPR are bacteria belonging to different groups that live in the rhizospheric region of the plant in association with roots or on the root surfaces (Maheshwari et al., 2012). Bacteria translocate from the soil's surface to the plant rhizosphere and start colonization in the rhizospheric zone of plant roots (Hafeez et al., 2013). All those bacteria that enhance the growth and development of plants fall under the category of PGPR (Hayat et al., 2010, Hafeez et al., 2013). It has been demonstrated by Noulas et al. (2018) that the enhancement in development and productivity of the PGPR inoculated plants was achieved due to the increased uptake of nutrients and the improved nutrient status in the plant. Some strains of $\mathrm{Zn}$ solubilizing bacteria can solubilize nutrients by producing phosphatases and organic acids, enhancing the accessibility of nutrients to the plants. PGPR enhance plant growth by various direct and indirect mechanisms. Directly they promote growth by synthesizing phytohormones and indirectly by getting involved in the accessibility of nutrients or acting as control agents (Yasmin et al., 2004).

In addition to some quantitative effects and plant growth promotion, PGPR also aids in increasing the concentration of macronutrients and micronutrients ( $\mathrm{Fe}$, $\mathrm{Zn}, \mathrm{P}, \mathrm{N}$ and $\mathrm{K}$ ) in tissues of plants and provides qualitative benefit to the plants (Imtiaz, 2003). Therefore, this is considered the latest and efficient approach to increase $\mathrm{Zn}$ in various crops. Some of the $\mathrm{Zn}$ solubilizing PGPR includes Acinetobacter spp., Pseudomonas spp., Trabusiella spp., Bacillus spp. Aeromonas spp., Arthrobacter spp., Gluconacetobacter spp., and Exiquobacterium spp. (Sillanpaa, 1990; Imtiaz, 2003). These bacteria significantly increase the growth and productivity of the plants. They also improve the overall quality of crops via the synthesis of growth-promoting hormones and various vitamins. The application of $\mathrm{Zn}$ solubilizing rhizobacteria as bio inoculants to enhance the yield of various crops such as barley, maize, rice and wheat has been very well documented. Tariq et al. (2007) reported a significant alleviation from $\mathrm{Zn}$ deficiency and a substantial increase in the tota biomass, grain yield and harvest index of rice crop. It also increased the zinc concentration in the rice grains.

Table 1 Bacterial species isolated from different sources and potential bio inoculants to ameliorate the $\mathrm{Zn}$ status in the plants

\begin{tabular}{lcc}
\hline Bacterium & Zn Source used in solubilization & Crop/location \\
\hline Pseudomonas fluorescens & Zn phosphate & Forest soil
\end{tabular}

Stenotrophomonas maltophilia,

Mycobacterium brisbanense, Enterobacter

aerogenes, Pseudomonas aeruginosa and

banana, chili, field bean,

Xanthomonas retroflexus.

$\mathrm{Zn}$ oxide and $\mathrm{Zn}$ phosphate

ground nut, maize, sugarcane, sorghum and tomato

\begin{tabular}{|c|c|c|c|}
\hline Pseudomonas Aeruginosa & Zn oxide, $\mathrm{Zn}$ phosphate & Air (tannery) & Fasim et al.,2002 \\
\hline Gluconacetobacter diazotrophicus & Zn Oxide, $\mathrm{Zn}$ carbonate & Maize & Sarathambal et al., 2010 \\
\hline Acinetobacter sp. & Zn oxide and Zn Carbonate & Rice & Gandhi et al.,2016 \\
\hline Bacillus aryabhattai & Zn oxide, Zn Carbonate and Zn Phosphate & Soybean and wheat & Ramesh et al.,2014 \\
\hline $\begin{array}{l}\text { Bacillus aerius ,Bacillus xiamenensis, } \\
\text { Burkholderia cenocepacia, Burkholderia } \\
\text { ambifaria and Sphingobacterium multivorum }\end{array}$ & Zn oxide, $\mathrm{Zn}$ carbonate & Rice & Nepomuceno et al.,2020 \\
\hline
\end{tabular}

Pseudomonas fragi, Pantoea dispersa,

Pantoea agglomerans, E. cloacae, Rhizobium

Zn Carbonate,Zn sulphate, $\mathrm{Zn}$ oxide, $\mathrm{Zn}$ phosphate

wheat

Kamran et al.,2017

sp.

Serratia liquefaciens, S. marcescens and

Bacillus thuringiensis.

Zn oxide, Zn Carbonate, Zn Sulphide and Zn

Phosphate

Wheat

Abaid et al., 2015

Furthermore, a notably positive impact on root weight, root length, root area, roo volume, and shoot weight was determined. The inoculated one exhibited significant $\mathrm{Zn}$ mobility as compared to uninoculated and control. PGPR solubilized the $\mathrm{Zn}$ with efficiency in the liquid culture as well. The $\mathrm{Zn}$ mobilizing strains are isolated from the rhizosphere of various crops. The isolated strains are screened by using a plate assay method. The efficient $\mathrm{Zn}$ solubilizers formed clear halo zones over the media contains insoluble zinc forms. Yasmin (2004) isolated Pseudomonas sp. from the rhizospheric soil of rice crop and determined its $\mathrm{Zn}$ mobilizing ability. It enhanced the $\mathrm{Zn}$ solubilization and improved yield, and increased $\mathrm{Zn}$ concentrations in rice plants. Similarly, Sirohi et al. (2015) reported $\mathrm{Zn}$ biofortification in wheat crops using Pseudomonas strain isolated from the rhizosphere of wheat. Mumtaz et al. (2017) reported the application of Bacillus sp. in maize. Bacillus aryabhattai and Bacillus subtilis significantly promoted the productivity of the maize crop. Thus, these bacteria are potential inoculants for biofortification to deal with malnutrition in populations where it is grown as a major cereal crop. 


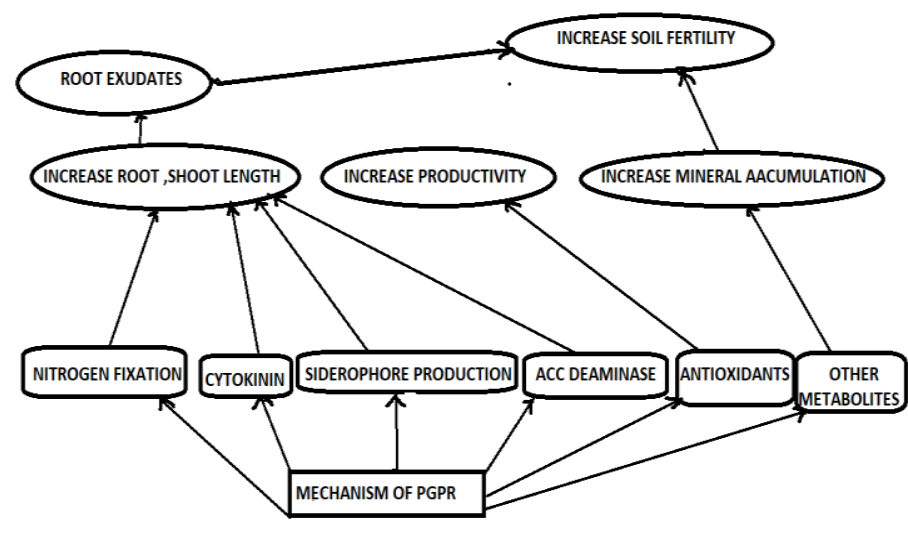

Figure 2 Summarize mechanism of PGPR

\section{Zn solubilizing bacteria in consortium}

It is well-conceived that PGPR present around the roots of a specific crop can also be inoculated in the different locality and for the different crop. They are found to promote plant growth significantly. In most of the studies, PGPR has been used as a single culture as biofertilizers. In contrast, some work has been done using more than one bacterial species. They are found to grow well in a similar soil environment. This microbial combination of more than two microbial species working together as a microbial community for promoting plant growth is called consortium. These bacterial isolates can be from the plant's rhizosphere or can be taken from the non-rhizosphere zone to work together as a consortium (Pandey et al., 2012).

Consortium formed using bacterial and fungal species has been applied to the sugar cane crop. It increased the sugar level significantly. It also reduced the need to apply Zn sulphate fertilizer by $75 \%$ (Deshmukh D.P et al., 2019). Strains of Bacillus cereus, B. subtilis and Serratia sp. used in consortium reduced the soil-borne disease in sweet pepper. The consortium protected the plant from the pathogens, and hence via an indirect mechanism, it acted as a biocontrol agent. The consortium also acted as biofertilizers by increasing the productivity of the crop (Raklami et al., 2019). The consortium of bacterial and mycorrhizae fung stimulates the germination of spores, root colonization of the bacteria, and multiplies the population of other valuable bacteria in the rhizospheric soil. The synergy of bacteria and mycorrhizae enhances the nitrogenase activity in the bacteria associated with nitrogen fixation in the rhizosphere. This leads to an improvement in atmospheric nitrogen fixation. This consortium has an excellent ability to infect the plant root and enhance the shoot length, root length, biomass and overall productivity of the plants (Raklami $\boldsymbol{e t}$ al., 2019). The consortium also improves soil fertility by changing the physicochemical and nutritional characteristic of the soil. Baslam et al. (2014) reported that the overall fertility of the soil had been improved after the application of consortium. Physicochemical characteristics of soil were found to be improved after the harvest of the crop grown with the consortium. The synergy has increased the organic matter and the concentration of carbon in the soil. It has also enhanced rhizospheric nitrogen and phosphorous. This improvement in the nutritional value of the soil is due to the capability of these bacteria to metabolize various organic compounds that are synthesized by the roots of the plants like various amino acids, carbohydrates and organic acids (Caravaca et al., 2003).

\section{CONCLUSION}

Micronutrients are required for many cellular and metabolic activities in plants. These nutrients are required in trace amounts but are of greater significance in plants. The adequate supply of these microelements to plants requires proper uptake, accumulation, mobilization, and storage in the plants (Hänsch and Mendel, 2009). The inadequate supply of micronutrients dramatically affects the productivity of crops throughout the world. For obtaining optimal productivity in plants, there should be a continuous supply of micronutrients in the maturation phase of plants. $\mathrm{Zn}$ is a vital micronutrient in higher plants and has many biochemical, physiological roles in plants. Inorganic $\mathrm{Zn}$ applied in the soil readily becomes unavailable after application. This conversion reduces $\mathrm{Zn}$ availability to plants. $\mathrm{Zn}$ deficiency leads to severe effects in plants and dramatically reduces their productivity.

The application of rhizobacterium is a recent approach used for increasing the availability of essential elements such as $\mathrm{Zn}$ and $\mathrm{Fe}$ in different crops. Using $\mathrm{Zn}$ solubilizing rhizobacteria found in rhizosphere soil has been shown to improve the quality and productivity of crops. These bacteria can also mobilize micronutrients and are excellent alternatives to Chemical fertilizers in dealing with $\mathrm{Zn}$ deficiency. The application of PGPR is considered the new technological approach to combat $\mathrm{Zn}$ deficiency problems in plants effectively by enhancing the bioavailability of $\mathrm{Zn}, \mathrm{Fe}$, and other micro and macronutrients through economic and eco-friendly aspect.

\section{REFERENCES}

Abaid-Ullah, M., Nadeem, M., Hassan, M., Ganter, J., Muhammad, B., Nawaz, K., \& Hafeez, F. Y. (2015). Plant growth promoting rhizobacteria: an alternate way to improve yield and quality of wheat (Triticum aestivum). International Journal of Agriculture and Biology, 17(1), 51-60. https://doi.org/10.1007/978-3642-37241-4_9

Alam, M. N., Abedin, M. J., \& Azad, M. A. K. (2010). Effect of micronutrients on growth and yield of onion under calcareous soil environment. International Research Journal of Plant Science, 1(3), 056-061. http://www.innspub.net/wpcontent/uploads/IJB-V2No8-p95-101.pdf

Alloway, B.J.(2001).Zn-the vital micronutrient for healthy, high-value crops.(VOL.).Brussels, Belgium:Zn in Soils and Crop Nutrition.

Alloway, B.J.(2002).Zn-the vital micronutrient for healthy, high-value crops.(VOL.).Brussels, Belgium:Zn in Soils and Crop Nutrition.

Alscher, R. G., Donahue, J. L., \& Cramer, C. L. (1997). Reactive oxygen species and antioxidants: relationships in green cells. Physiologia Plantarum, 100(2), 224-233. https://doi.org/10.1111/j.1399-3054.1997.tb04778.x

Auld, D. S., \& Bergman, T. (2008). Medium-and short-chain dehydrogenase/reductase gene and protein families: The role of zinc for alcohol dehydrogenase structure and function. Cellular and molecular life sciences: CMLS, 65(24), 3961-3970. https://doi.org/10.1007/s00018-008-8593-1

Bailey, S., Thompson, E., Nixon, P. J., Horton, P., Mullineaux, C. W., Robinson, C., \& Mann, N. H. (2002). A critical role for the Var2 FtsH homologue of Arabidopsis thaliana in the photosystem II repair cycle in vivo. Journal of Biological Chemistry, 277(3), https://doi.org/10.1074/jbc.m105878200

Barman, H., Das, S.K.\& Roy, A.(2018). Zn in soil environment for plant health and management strategy. Universal Journal of Agricultural Research, 6 (5),149154. https://doi.org/10.13189/ujar.2018.060501

Baslam, M., Qaddoury, A., \& Goicoechea, N. (2014). Role of native and exotic mycorrhizal symbiosis to develop morphological, physiological and biochemical responses coping with water drought of date palm, Phoenix dactylifera. Trees 28 , 161-172. https://doi.org/10.1007/s00468-013-0939-0

Bowen, G. D., Skinner, M. F., \&Bevege, D. I. (1974). Zn uptake by mycorrhizal and uninfected roots of Pinus radiata and Araucaria cunninghamii. Soil Biology and Biochemistry, 6(3), 141-144. https://doi.org/10.1016/0038-0717(74)90017-0 Brennan, R. F. (2005). Zn application and its availability to plants (Doctoral dissertation, Murdoch University).

Broadley, M. R., White, P. J., Hammond, J. P., Zelko, I., \& Lux, A. (2007). Zn in plants. New phytologist, 173(4), 677-702. https://doi.org/10.1111/j.14698137.2007.01996.x

Brown, P. H., Cakmak, I., \& Zhang, Q. (1993). Form and function of Zn plants. In Zn in soils and plants, 93-106.https://doi.org/10.1007/978-94-011-0878-2 7

Cabot, C., Martos, S., Llugany, M., Gallego, B., Tolrà, R.\&Poschenrieder, C.(2019). A role for $\mathrm{Zn}$ in plant defense against pathogens and herbivores. Frontiers in plant science, 10, 1171. https://doi.org/10.3389/fpls.2019.01171

Cakmak, I. (2000). Tansley Review No. 111: possible roles of $\mathrm{Zn}$ in protecting plant cells from damage by reactive oxygen species. New Phytologist, 146(2), 185-205. https://doi.org/10.1046/j.1469-8137.2000.00630.x

Cakmak, I.,\& C. Engels. (1999). Role of mineral nutrients in photosynthesis and yield formation. Mineral Nutrition of Crops:mechanisms and implications. Haworth Press. N. Y., USA,141-168.

Caravaca, F., Barea, J. M., Palenzuela, J., Figueroa, D., Alguacil, M. M., \& Roldán, A. (2003). Establishment of shrub species in a degraded semiarid site after inoculation with native or allochthonous arbuscular mycorrhizal fungi. Applied Soil Ecology,22(2), 103-111. https://doi.org/10.1016/s09291393(02)00136-1

Castillo-González, J., Ojeda-Barrios, D., Hernández-Rodríguez, A., GonzálezFranco, A. C., Robles-Hernández, L., \& López-Ochoa, G. R. (2018). Zinc metalloenzymes in plants. Interciencia, 43(4), 242-248.

Coleman, J. E.(1992). Zn proteins: enzymes, storage proteins, transcription factors, and replication proteins. Annual Review of Biochemistry,61,897-946. https://doi.org/10.1146/annurev.bi.61.070192.004341

Das, S.K., Avasthe, R.K., Singh, M., Dutta, S.K.\& Roy, A.(2018). Zn in plantsoil system and management strategy. Agrica, 7(1),1-6. https://doi.org/10.5958/2394-448x.2018.00001.9

Dell, B., \& Wilson, S. A. (1985). Effect of Zn supply on growth of three species of Eucalyptus seedlings and wheat. Plant and Soil, 88(3), 377-384. https://doi.org/10.1007/bf02197494

Deshmukh, D. P., Navale, A. M., \& Deokar, C. D. (2019). Influence of Zinc Solubilising Consortiums on Yield Parameters of Suru Sugarcane.

Diatta, J., \& Kocialkowski, W. (1998). Adsorption of zinc in some selected soils. Polish Journal of Environmental Studies, 7, 195-200.

Di Simine, C. D., Sayer, J. A., \& Gadd, G. M. (1998). Solubilization of Zn phosphate by a strain of Pseudomonas fluorescens isolated from a forest 
soil. Biology and Fertility

of Soils, 28(1),

$87-94$

Disante, K., D. Fuentes.,J. Cortina. (2010). Response to drought of Zn-stressed Quercus suber L. Seedlings. Environment and Experimental Botany, 70(2),96103. https://doi.org/10.1016/j.envexpbot.2010.08.008

Dos Santos, G. C. G., Valladares, G. S., Abreu, C. A., de Camargo, O. A., \& Grego, C. R. (2013). Assessment of copper and zinc in soils of a vineyard region in the state of São Paulo, Brazil. Applied and Environmental Soil Science. https://doi.org/10.1155/2013/790795

Dubeikovsky, A. N., Mordukhova, E. A., Kochetkov, V. T., Polikarpova, F. Y. \& Boronin, A. M. (1993). Growth promotion of blackcurrant softwood cuttings by recombinant strain Pseudomonas fluorescens BSP53a synthesizing an increased amount of indole-3-acetic acid. Soil biology and Biochemistry, 25(9), 1277-1281. https://doi.org/10.1016/0038-0717(93)90225-Z

Efe, L., \&Yarpuz, E., (2011). The effect of Zn application methods on seed cotton yield, lint, and seed quality of cotton (Gossypium hirsutumL.) in eas Mediterranean region of Turkey. African Journal of Biotechnology, 10(44), 8782 8789. https://doi.org/10.5897/AJB11.737

Eide, D. J. (2011). The oxidative stress of zinc deficiency. Metallomics, 3(11) 1124-1129 https://doi.org/10.1039/c1mt00064k

F, Fasim., N, Ahmed., R, Parsons., Geoffrey, M. Gadd. (2002). Solubilization of $\mathrm{Zn}$ salts by a bacterium isolated from the air environment of a tannery, FEMS Microbiology 6968.2002.tb11277.x

Forde, B. G.,\& Lea, P. J. (2007). Glutamate in plants: metabolism, regulation, and signalling. Journal of Experimental Botany, 58(9),2339-2358. https://doi.org/10.1093/jxb/erm121

Gandhi, A., \& Muralidharan, G. (2016). Assessment of Zn solubilizing potentiality of Acinetobacter sp. isolated from rice rhizosphere. European Journal of Soil Biology, 76, 1-8. https://doi.org/10.1016/j.ejsobi.2016.06.006

Gao, X. P., Zhang, F. S.,\&Hoffland, E.(2009). Malate exudation by six aerobic rice genotypes varying in $\mathrm{Zn}$ uptake efficiency. Journal of Environmentalquality,38(6), 2315-2321. https://doi.org/10.2134/jeq2009.0043 Genc, Y., Verbyla, A. P., Torun, A. A., Cakmak, I., Willsmore, K., Wallwork, H., \& McDonald, G. K. (2009). Quantitative trait loci analysis of Zn efficiency and grain $\mathrm{Zn}$ concentration in wheat using whole genome average interval mapping. Plant and Soil, 314(1-2), 49.https://doi.org/10.1007/s11104-008-9704-

Glick, B. R. (1995). The enhancement of plant growth by free-living bacteria. Canadian journal of microbiology,41(2), 109-117. https://doi.org/10.1139/m95-015

Golubović, T. A. T. J. A. N. A., \& Blagojević, B. O. J. K. A. (2012). Transfer and bioaccumulation of heavy metal ions from soil into plants. Safety engineering, 2(1), 1-4. https://doi.org/10.7562/se2012.2.01.01

Goldberg JM, Lippard SJ. New Tools Uncover New Functions for Mobile Zn in the Brain. Biochemistry. 2018 Jul;57(27):3991-3992. DOI: 10.1021/acs.biochem.8b00108.Graham RD, Senadhira D, Beebe S, Iglesias C, Monasterio I.

1999. Breeding for micronutrient density in edible portions of staple food crops: conventional approaches. Field Crops

Research 60, 57 \pm 80 .

Graham RD, Senadhira D, Beebe S, Iglesias C, Monasterio I.

1999. Breeding for micronutrient density in edible portions of staple food crops: conventional approaches. Field Crops

Research 60, 57 \pm 80 .

Graham,R. D., Senadhira, D., Beebe, S., Iglesias, C., \&Monasterio I. (1999) Breeding for micronutrient density in edible portions of staple food crops: conventional approaches. Field Crops Research, 60(1-2), 57-80. https://doi.org/10.1016/s0378-4290(98)00133-6

Grewal, H. S. (2001). Zinc influences nodulation, disease severity, leaf drop and herbage yield of alfalfa cultivars. Plant and Soil,234(1), 47-59. https://doi.org/10.1023/A:1010544601267

Graham, R.D., Ascher, J.S., \& Hynes, S.C.(1992). Selecting Zn-efficient cerea genotypes for soils of low $\mathrm{Zn}$ status. Plant Soil 146(1-2), 241-250. https://doi.org/10.1007/BF00012018

Grusak, Michael A., \& Dean DellaPenna.(1999). "Improving the nutrient composition of plants to enhance human nutrition and health." Annual review of plant biology ,50(1),133-161. https://doi.org/10.1146/annurev.arplant.50.1.133 Gupta, N., Ram, H., \& Kumar, B. (2016). Mechanism of Zn absorption in plants uptake, transport, translocation, and accumulation. In Reviews in Environmental Science and Biotechnology, 15(1), 89-109. https://doi.org/10.1007/s11157-0169390-1

Hacisalihoglu, G.,\&Kochian, L. V.(2003). How do some plants tolerate low levels of soil Zn? Mechanisms of Zn efficiency in crop plants. New Phytologist 159(2), 341-350. https://doi.org/10.1046/j.1469-8137.2003.00826.x

Hafeez, F. Y., Abaid-Ullah, M., \& Hassan, M. N. (2013). Plant growthpromoting rhizobacteria as $\mathrm{Zn}$ mobilizers: A promising approach for cereals biofortification. In Bacteria in Agrobiology: Crop Productivity,217-235. Springer-Verlag Berlin Heidelberg. https://doi.org/10.1007/978-3-642-37241-4_9
Hänsch, R., \& Mendel, R. R. (2009). Physiological functions of minera micronutrients (cu, $\mathrm{Zn}, \mathrm{Mn}, \mathrm{Fe}, \mathrm{Ni}, \mathrm{Mo}, \mathrm{B}, \mathrm{cl})$. Current opinion in plant biology, 12(3), 259-266.https://doi.org/10.1016/j.pbi.2009.05.006

Haslett, B. S., Reid, R. J., \&Rengel, Z. (2001). Zn mobility in wheat: uptake and distribution of $\mathrm{Zn}$ applied to leaves or roots. Annals of Botany, 87(3), 379-386. https://doi.org/10.1006/anbo.2000.1349

Hayat, R., Ali S., Amara, U., Khalid, R.,\& Ahmed, I. (2010). Soil beneficial bacteria and their role in plant growth promotion: a review. Annals of Microbiology, 60(4), 579-598. https://doi.org/10.1007/s13213-010-0117-1

Helfenstein, J., Pawlowski, M. L., Hill, C. B., Stewart, J., Lagos-Kutz, D., Bowen, C. R., ... \& Hartman, G. L. (2015). Zn deficiency alters soybean susceptibility to pathogens and pests. Journal of Plant Nutrition and Soil Science, 178(6), 896-903. https://doi.org/10.1002/jpln.201500146

Holloway, R. E. (1996). Zn as a subsoil nutrient for cereals/by RE Holloway (Doctoral dissertation). http://hdl.handle.net/2440/18920

Huber, D. M., \& Wilhelm, N. S. (1988). The role of manganese in resistance to plant diseases. In Manganese in soils and plants, 155-173. https://doi.org/10.1007/978-94-009-2817-6_12

Imtiaz, M. (2003). Zn Contents in the Seed of Some Domestic and Exotic Wheat Genotypes M. Imtiaz," BJ Alloway, KH Shah, SH Siddiqui, MY Memon, M. Aslam and P. Khan. Asian Journal of Plant Sciences, 2(15-16), 1118-1120 https://doi.org/10.3923/ajps.2003.1118.1120

Imtiaz, M., Alloway, B.J., Shah, K.H., Siddiqui, S.H., Memon, M.Y., Aslam, M.\& Khan, P.(2003). Zn nutrition of wheat: II: Interaction of Zn with other trace elements. Asian Journal of Plant Sciences, 2(2), 156-160. https://doi.org/10.3923/ajps.2003.152.155

Jamil, M. (2015). Plant Growth Promoting Rhizobacteria: An Alternate Way to Improve Yield and Quality of Wheat (Triticum aestivum). Proceedings of the National Academy of Sciences, 111(6). https://doi.org/10.1073/pnas.1317360111 Jiang, W., Struik, P. C., Lingna, J., van, K. H., Zhao, M.,\&Stomph, T. J(2007) Uptake and distribution of root-applied or foliar applied ${ }^{65} \mathrm{Zn}$ after flowering in aerobic rice. Annals of Applied biology,150(3), 383-391. https://doi.org/10.1111/j.1744-7348.2007.00138.x

Kamalakannan, S., Manikandan, R., Haripriya, K., Sudhagar, R., \& Kumar, S (2019). Effect of zinc sulphate and biofertilizers on yield attributes and yield of okra [Abelmoschus esculentus (L.) Moench]. Research on Crops, 20(4).

Kamran, S., Shahid, I., Baig, D. N., Rizwan, M., Malik, K. A., \&Mehnaz, S. (2017). Contribution of $\mathrm{Zn}$ solubilizing bacteria in growth promotion and $\mathrm{Zn}$ content of wheat. Frontiers in Microbiology, 8(DEC), 2593 https://doi.org/10.3389/fmicb.2017.02593

Kasim, W. A. (2007). Physiological consequences of structural and ultrastructural changes induced by $\mathrm{Zn}$ stress in Phaseolus vulgaris. I. Growth and Photosynthetic apparatus. Int. J. Bot. 3(1),15-22 https://doi.org/10.3923/ijb.2007.15.22

Kirk, G. J. D., \&Bajita, J. B. (1995). Root-induced iron oxidation, pH changes and $\mathrm{Zn}$ solubilization in the rhizosphere of lowland rice. New Phytologist, 131(1) 129-137. https://doi.org/10.1111/i.1469-8137.1995.tb03062.x

Li, Z., Fan, Y. C., Gao, L., Cao, X, Ye, J. L., \& Li, G. H. (2016). The dual roles of $\mathrm{Zn}$ sulfate in mitigating peach gummosis. Plant Disease, 100(2), 345-351. https://doi.org/10.1094/pdis-01-15-0131-re

Lin, C. W., Chang, H. B., \& Huang, H. J. (2005). Zn induces mitogen-activated protein kinase activation mediated by reactive oxygen species in rice roots. Plant

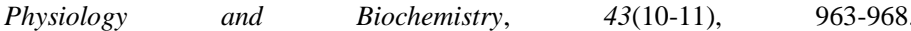
https://doi.org/10.1007/s10725-005-0162-0

Liu, D.-Y., Liu, Y.-M., Zhang, W., Chen, X.-P., \& Zou, C.-Q. (2019). Zn Uptake, Translocation, and Remobilization in Winter Wheat as Affected by Soil Application of $\mathrm{Zn}$ Fertilizer. Frontiers in Plant Science, 10, 426. https://doi.org/10.3389/fpls.2019.00426

Liu, SL., Yang, RJ., Ma, MD. (2015). Effects of exogenous NO on the growth mineral nutrient content, antioxidant system, and ATPase activities of Trifolium repens L. plants under cadmium stress. Acta Physiologiae Plantarum, 37, 1721. https://doi.org/10.1007/s11738-014-1721-7

López-Millán, A. F., D. R. Ellis. \& M. A. Grusak. (2005). Effect of Zn and manganese supply on the activities of superoxide dismutase and carbonic anhydrase in Medicago truncatula wild type and razmutant plants. Plant Science, 168(4),1015-1022. https://doi.org/10.1016/j.plantsci.2004.11.018

Loneragan, J.F.\& M.J. Webb (1993) Interactions between $\mathrm{Zn}$ and Other Nutrients Affecting the Growth of Plants. Chap 9 in Robson, A.D. (ed.) $\mathrm{Zn}$ in Soils and Plants, Kluwer Academic Publishers, Dordrecht, 119-134.

Machado, P. P., Steiner, F., Zuffo, A. M.\& Machado, R. A. (2018). Could the supply of boron and $\mathrm{Zn}$ improve resistance of potato to early blight? Potato Research,61(2),169-182. https://doi.org/10.1007/s11540-018-9365-4

Maheshwari, D.K., Kumar, S., Maheshwari, N.K., Patel, D. \& Saraf, M. (2012) Nutrient availability and management in the rhizosphere by microorganisms Bacteria in Agrobiology: Stress Management, Springer-Verlag, Berlin Heildelberg, 301-326. https://doi.org/10.1007/978-3-642-23465-1_15

Marschner H. (1993) Zn Uptake from Soils. Zn in Soils and Plants. Developments in Plant and Soil Sciences, vol 55. Springer, Dordrecht. https://doi.org/10.1007/978-94-011-0878-2_5 
McAllister, B. B.,\& Dyck, R. H. (2017). Zn transporter 3 (ZnT3) and vesicular $\mathrm{Zn}$ in central nervous system function. Neuroscience \&Biobehavioral Reviews, 80, 329-350.https://doi.org/10.1016/j.neubiorev.2017.06.006

McCall, K. A., Huang, C. C., \&Fierke, C. A. (2000). Function and mechanism of $\mathrm{Zn}$ metalloenzymes. Journal of Nutrition, 130(5 SUPPL.), 1437-1446. https://doi.org/10.1093/jn/130.5.1437s.

McCracken, L. M., Blednov, Y. A., Trudell, J. R., Benavidez, J. M., Betz, H., \& Harris, R. A. (2013). Mutation of a zinc-binding residue in the glycine receptor $\alpha 1$ subunit changes ethanol sensitivity in vitro and alcohol consumption in vivo. Journal of Pharmacology and Experimental Therapeutics, 344(2), 489-500. DOI: https://doi.org/10.1124/jpet.112.197707

Moreno-Jiménez, E., Plaza, C., Saiz, H., Manzano, R., Flagmeier, M., \& Maestre, F. T. (2019). Aridity and reduced soil micronutrient availability in global drylands. Nature sustainability, 2(5), 371-377. https://doi.org/10.1038/s41893019-0262-x

Mousavi,S.R., Galavi, M.,\&Ahmadvand, G. 2007. Effect of Zn and manganese foliar application on yield, quality, and enrichment on potato (Solanum tuberosum L.)Asian Journal of Plant Sciences, 6(8),1256-1260.

Mousavi,S.R., Shahsavari, M.,\& Rezaei, M.(2011). A general overview on manganese (Mn) importance for crops production. Australian Journal of Basic and Applied Sciences,5(9),1799-1803. http://www.insipub.com/ajbas/2011/September-2011/1799-1803.pdf

Mertens J., Smolders E. (2013) Zn. Heavy Metals in Soils. Environmental Pollution (vol 22). Springer, Dordrecht. https://doi.org/10.1007/978-94-0074470-7 17

Mousavi, S.R., Galavi, M.\& Rezaei, M.(2012). The interaction of Zn with other elements in plants: a review. International Journal of Agriculture and Crop Sciences, 4(24), 1881-1884.

Mumtaz, M.Z., Ahmad, M., Jamil, M. \& Hussain, T.(2017). Zn solubilizing Bacillus spp. potential candidates for biofortification in maize. Microbiological research, 202, 51-60. https://doi.org/10.1016/j.micres.2017.06.001

Nepomuceno, R. A., Brown, C. B., Gargarino, A. M. P., Pedro, M. S., \& Brown, M. B. (2020). Growth Enhancement of Rice (Oryza sativa L.) by ZincSolubilizing Bacteria Isolated from Vesicular-Arbuscular Mycorrhizal Root Inoculant (VAMRI). Philippine Journal of Crop Science (PJCS), 45(1), 34-40. https://doi.org/10.1007/978-981-13-9431-7_3

Noulas, C., Tziouvalekas, M., \& Karyotis, T. (2018). Zn in soils, water and food crops. In Journal of Trace Elements in Medicine andBiology,49, 252-260. https://doi.org/10.1016/j.jtemb.2018.02.009

Patel, K., Kumar, A., \& Durani, S. (2007). Analysis of the structural consensus of the zinc coordination centers of metalloprotein structures. Biochimica et Biophysica Acta (BBA)-Proteins and Proteomics, 1774(10), 1247-1253. https://doi.org/10.1016/j.bbapap.2007.07.010

Pandey, P., Bisht, S., Sood, A., Aeron, A., Sharma, G. D., \& Maheshwari, D. K (2012). Consortium of plant-growth-promoting bacteria: Future perspective in agriculture. Bacteria in agrobiology: plant probiotics, 185-200 https://doi.org/10.1007/978-3-642-27515-9 10

Pawar A., Ismail S., Mundhe S., Patil V. D. (2015). Solubilization of insoluble $\mathrm{Zn}$ compounds by different microbial isolates in vitro condition. Internationzl $\begin{array}{llll}\text { Journal of Tropical } & \text { Agriculture, 33(2), 865-869. }\end{array}$ http://serialsjournals.com/archives.php?journals_id=56

Peck, A. W., \& McDonald, G. K. (2010). Adequate Zn nutrition alleviates the adverse effects of heat stress in bread wheat. Plant and soil, 337(1-2), 355-374. https://doi.org/10.1007/s11104-010-0532-X

Prasad, R., Shivay, Y. S., \& Kumar, D. (2016). Interactions of Zn with other nutrients in soils and plants-a Review. Indian Journal of Fertilisers, 12(5), 1626. https://doi.org/10.1201/9781315372327-6

Ramesh, A., Sharma, S. K., Sharma, M. P., Yadav, N., \& Joshi, O. P. (2014). Inoculation of $\mathrm{Zn}$ solubilizing Bacillus aryabhattai strains for improved growth mobilization and biofortification of $\mathrm{Zn}$ in soybean and wheat cultivated in Vertisols of central India. Applied Soil Ecology, 73, 87-96. https://doi.org/10.1016/j.apsoil.2013.08.009

Raklami, A., Bechtaoui, N., Tahiri, A. I., Anli, M., Meddich, A., \& Oufdou, K. (2019). Use of rhizobacteria and mycorrhizae consortium in the open field as a strategy for improving crop nutrition, productivity and soil fertility. Frontiers in Microbiology, 10, 1106. https://doi.org/10.3389/fmicb.2019.01106

Rutkowska, B., Szulc, W., Bomze, K., Gozdowski, D., \&Spychaj-Fabisiak, E. (2015). Soil factors affecting solubility and mobility of $\mathrm{Zn}$ in contaminated soils. International Journal of Environmental Science and Technology, 12(5), 1687-1694. https://doi.org/10.1007/s13762-014-0546-7

Salah, E., Turki, A. \&Mahal, S. (2015) Chemometric Evaluation of the Heavy Metals in Urban Soil of Fallujah City, Iraq. Journal of Environmental Protection, 6(11), 1279-1292.https://doi.org/10.4236/jep.2015.611112

Sadeghzadeh A.(2013) A review of Zn nutrition and plant breeding Journal of Soil Science and Plant Nutrition., 13 (4), 905-927. https://doi.org/10.4067/s0718-95162013005000072

Sajwan, K. S., \& Lindsay, W. L. (1988). Effect of redox, Zn fertilization and incubation time on DTPA-extractable $\mathrm{Zn}$, iron and manganese. Communications in soil science and plant analysis, 19(1), 1-11. https://doi.org/10.1017/s0021859600083039
Sarathambal, C., Thangaraju, M., Paulraj, C.(2010). Assessing the Zn solubilization ability of Gluconacetobacterdiazotrophicus in maize rhizosphere using labelled ${ }^{65} \mathrm{Zn}$ compounds. Indian Journal of Microbiology, 50, 103-109. https://doi.org/10.1007/s12088-010-0066-1

Shambhavi, S., Kumar, R., Padbhushan, R., Verma, G., Sharma, S.P., Sharma, S.K. \& Sharma, R.P., (2019). Dynamics of $\mathrm{Zn}$ under long term application of chemical fertilizers and amendments by maize-wheat cropping sequence in Typic Hapludalfs. Soil Use and Management, 36(3),507523.https://doi.org/10.1111/sum.12566

Sharma, A., Patni, B., Shankhdhar, D., \&Shankhdhar, S. C. (2013). Zn - An Indispensable Micronutrient. In Physiology and Molecular Biology of Plant,19(1),11-20. Springer. https://doi.org/10.1007/s12298-012-0139-1.

Shri, P. U., \& Pillay, V. (2017). Excess of soil zinc interferes with uptake of other micro and macro nutrients in Sorghum bicolor (L.) plants. Indian Journal of Plant Physiology, 22(3), 304-308. https://doi.org/10.1007/s40502-017-0313$\underline{0}$

Shukla, A. K., Behera, S. K., Satyanarayana, T., \&Majumdar, K.(2009) Importance of Micronutrients in Indian Agriculture. Better crops- South Asia,11, 6-10.

Sindhu, S. S., Sharma, R., Sindhu, S., \&Phour, M. (2019). Plant Nutrient Management Through Inoculation of $\mathrm{Zn}$-Solubilizing Bacteria for Sustainable Agriculture. In Biofertilizers for Sustainable Agriculture and Environment Soil Biology.55,173-201. Springer, Cham. https://doi.org/10.1007/978-3-03018933-4 8

Singh, Grewal. H. (2001). Zn influences nodulation, disease severity, leaf drop and herbage yield of alfalfa cultivars. Plant and Soil, 234(1), 47-59. https://doi.org/10.1023/a:1010544601267

Sillanpaa M. (1990). Micronutrients Assessment at the Country Level: An international Study. Food and Agriculture Organization of the United Nations, 63, 216.

Sirohi, G., Upadhyay, A., Srivastava, P.S.\& Srivastava, S.(2015). PGPR mediated $\mathrm{Zn}$ biofertilization of soil and its impact on growth and productivity of wheat. Journal of soil science and plant nutrition, 15(1), 202-216. https://doi.org/10.4067/s0718-95162015005000017

Sunithakumari, K., Devi, S. P., \& Vasandha, S. (2016). Zinc solubilizing bacterial isolates from the agricultural fields of Coimbatore, Tamil Nadu, India. Current Science, 196-205. https://www.jstor.org/stable/24906745.

Speir, T.W., Van Schaik, A.P., Percival, H.J. (2003). Heavy Metals in Soil, Plants and Groundwater Following High-Rate Sewage Sludge Application to Land. Water, Air, \& Soil Pollution 150,319-358. https://doi.org/10.1023/A:1026101419961

Tariq, M., Hameed, S., Malik, K.A.,\& Hafeez, F.Y. (2007) Plant root associated bacteria for Zn mobilization in rice. Pakistan Journal of Botany, 39(1),245-253. https://doi.org/10.1007/1-4020-3570-5_62

Tavallali, V., Rahemi, M., Eshghi, S., Kholdebarin, B., \& Ramezanian, A. (2010). Zn alleviates salt stress and increases antioxidant enzyme activity in the leaves of pistachio (Pistacia vera L.'Badami') seedlings. Turkish Journal of Agriculture and Forestry, 34(4), 349-359. https://doi.org/10.3923/rjes.2009.656.666

Tsonev, T., \& Cebola Lidon, F.J.(2012). Zn in plants-an overview. Emirates Journal of Food \& Agriculture (EJFA), 24(4),322-333. https://doi.org/10.9755/ejfa.v24i6.502509

Vacheron, J., Desbrosses, G., Bouffaud, M. L., Touraine, B., Moënne-Loccoz, Y., Muller, D., ... \& Prigent-Combaret, C. (2013). Plant growth-promoting rhizobacteria and root system functioning. Frontiers in plant science, 4, 356. https://doi.org/10.3389/fpls.2013.00356

Vitosh, M. L., Warncke, D. D., \& Lucas, R. E. (1998). Secondary and Micronutrients for. Bulletin E-486, Michigan State University Extension Service, East Lansing, Michigan. http://www.plantgrower.org/uploads/6/5/5/4/65545169/e0486.pdf

Welch, R. M., \& Graham, R. D. (2002). Breeding crops for enhanced micronutrient content. In Food Security in Nutrient-Stressed Environments: Exploiting Plants' Genetic Capabilities (pp. 267-276). Springer, Dordrecht.245, 205-214. https://doi.org/10.1007/978-94-017-1570-6 29

Wheal, M., Rengel, Z.(1997). Chlorsulfuron reduces rates of Zn uptake by wheat seedlings from solution culture. Plant and Soil 188(2),309-317. https://doi.org/10.1023/A:1004256429979

Whiting, S. N., Leake, J. R., McGrath, S. P., \& Baker, A. J. (2001). Zn accumulation by Thlaspi caerulescens from soils with different $\mathrm{Zn}$ availability: a pot study. Plant and Soil, 236(1), 11-18. https://doi.org/10.1023/a:1011950210261

Widodo.,Broadley, M. R., Rose, T., Frei, M.,Pariasca-Tanaka, J.,Yoshihashi, T., Thomson, M., Hammond, J. P.,Aprile, A.,Close,T. J., Ismail, A. M.,\&Wissuwa, M. (2010).Response to $\mathrm{Zn}$ deficiency of two rice lines with contrasting tolerance is determined by root growth maintenance and organic acid exudation rates, and not by Zn-transporter activity. New Phytol, 186(2), 400-414. https://doi.org/10.1111/j.1469-8137.2009.03177.x

Wu, C.Y., Lu, L.L., Yang, X.E., Feng, Y., Wei, Y.Y., Hao, H.L., Stoffella, P.J. \& He, Z.L.(2010). Uptake, translocation, and remobilization of Zn absorbed at different growth stages by rice genotypes of different $\mathrm{Zn}$ densities. Journal of 
agricultural and food chemistry, 58(11), 6767-6773. https://doi.org/10.1021/jf100017e

Yamasaki, S., Sakata-Sogawa., K., Hasegawa., A., Suzuki, T., Kabu, K.,\& Sato, E. (2007). $\mathrm{Zn}$ is a novel intracellular second messenger. Journal of Cell Biology, 177(4), 637-645. https://doi.org/10.1083/jcb.200702081

Yang, X. E., Ye, Z. Q., Shi, C. H., Zhu, M. L.,\& Graham, R. D.(1998). Genotypic differences in concentrations of iron, manganese, copper, and $\mathrm{Zn}$ in polished rice grains. Journal of Plant Nutrition,21(7), 1453-1462. https://doi.org/10.1080/01904169809365495

Yasmin, S., Bakar, M.A.R., Malik, K.A. \& Hafeez, F.Y. (2004). Isolation, characterization, and beneficial effects of rice associated PGPRs from Zanzibar soils. Journal of Basic Microbiology, 44(3), 241-252.

https://doi.org/10.1002/jobm.200310344

Yosefi, K., Galavi, M., Ramrodi, M.,\& Mousavi, S.R.(2011). Effect of biophosphate and chemical phosphorus fertilizer accompanied with micronutrient foliar application on growth, yield, and yield components of maize (Single Cross 704). Australian Journal of Crop Science, 5(2),175-180. https://doi.org/10.5539/jas.v3n4p22

Zastrow, M. L., \& Pecoraro, V. L. (2014). Designing Hydrolytic Zinc
Metalloenzymes.
Biochemistry,
53(6),
957-978.

https://doi.org/10.1021/bi4016617 